\title{
ROZMOWY
}

\section{Henryk Suchar}

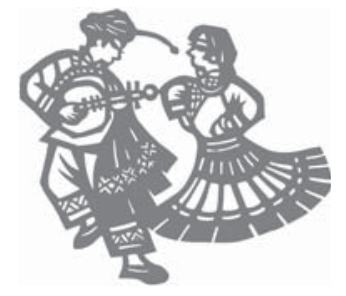

\section{WIETNAMSKA TOŻSAMOŚĆ - WYWIAD Z PREZYDENTEM WIETNAMU TRAN DUC LUONGIEM}

Pan Tran Duc Luong, Prezydent Socjalistycznej Republiki Wietnamu - odpowiada na pytania „Azji-Pacyfiku” przedstawione przez red. Henryka Suchara, z okazji oficjalnej wizyty w Polsce, 13-17 października 2003 r. Odpowiedzi na postawione wtedy pytania dotarły do Redakcji w styczniu 2003 r., za pośrednictwem Ambasady Wietnamu w Polsce, której Redakcja składa podziękowanie za pomoc. Odpowiedzi Prezydenta udzielone w języku angielskim przetłumaczył na polski H. Suchar. Objaśnienia w przypisach i w nawiasach kwadratowych pochodzą od Redakcji.

- Wietnam przechodzi obecnie transformację systemową, zainicjowaną polityką doi moi, tzw. odnowy. Proces ten podzielony był na fazy. Jak Pan Prezydent by je opisal?

W okresie poprzedzającym odnowę, Wietnam - tak jak inne państwa socjalistyczne - praktykował politykę rozwoju narodowego, zgodną z panującym wtedy modelem socjalizmu. Publiczna i kolektywna własność środków produkcji oraz gospodarka planowa, centralnie sterowana, odgrywały wówczas zasadniczą rolę.

Analizując rzeczywistość w duchu: ,szukaj prawdy, precyzyjnie oceniaj prawdę i mów tylko prawdę", Komunistyczna Partia Wietnamu (KPW) przeanalizowała niedociągnięcia oraz słabości mechanizmów centralnego planowania i przydzielania dotacji. Następnie podsumowano także wyniki akcji (trwającej od początku lat 80.) promowania na wsi wyodrębnionej własności i ocenione je jako dobre ${ }^{1}$. Uczyliśmy się na zarówno na udanych, jak i na nieudanych doświadczeniach re-

\footnotetext{
${ }^{1} \mathrm{~W}$ warunkach niemal pełnej kolektywizacji rolnictwa oznaczało to w praktyce stopniową odbudowę rodzinnej gospodarki chłopskiej, chociaż zachowano pewne elementy instytucjonalne pradawnych, a tam wciąż żywych tradycji wspólnot wiejskich [Redakcja].
} 
form oraz uprzemysłowienia, przeprowadzonych w innych krajach. Na VI Zjeździe Partii w 1986 roku, KPW postanowiła podjąć szeroko i dogłębnie kwestię odnowy, stawiając nacisk na reformy gospodarcze, w tym na zniesienie mechanizmu centralnego planowania i przydzielania dotacji, a przejść do budowy rynkowej gospodarki wielosektorowej, o socjalistycznej orientacji.

Odnowa ekonomiczna związana była z reformami we wszystkich dziedzinach - w kulturze, w sferze społecznej, bezpieczeństwa i obrony, jak też z budową socjalistycznego państwa prawa, należącego do ludu. Jednocześnie Wietnam, obok mobilizacji czynników wewnętrznych na rzecz reform, zmierzał do realizacji polityki otwartych drzwi w sferze zagranicznej, do zróżnicowania i dywersyfikacji swych stosunków międzynarodowych. Naszym pragnieniem było uzyskanie statusu partnera przyjaznego i wiarygodnego wobec wszystkich krajów wspólnoty międzynarodowej, uchylenie sankcji i embarga stosowanym jeszcze wtedy przeciwko naszemu państwu, a rozwój rynku i przyciągnięcie inwestycji zagranicznych.

Dzięki tej polityce gospodarka Wietnamu wyszła z ostrego kryzysu. Inflacja została zahamowana i spadła z poziomu około $700 \%$ w 1986 r., do $12 \%$ w 1995 r. Od tamtego czasu jest ona pod ścisłą kontrolą i wynosi 3-4\% rocznie. Między 1992 a 1998 r. wzrost produktu krajowego brutto (PKB) wynosił 8\% rocznie. W latach 1991-2000 nasz PKB zwiększył się dwukrotnie. W ostatnich latach, mimo spowolnienia trendów światowych i regionalnych, a także klęsk żywiołowych [w naszym kraju] i epidemii SARS w regionie, Wietnam był w stanie utrzymać wysokie tempo wzrostu, sięgające 7\%. W 2003 r. wyniosło ono 7,2\%. Podjęto kroki mające na celu zniesienie „systemu voucherowego" i subsydiowania przedsiębiorstw państwowych, a wprowadzenie nowej polityki monetarnej i fiskalnej. Postanowiono też położyć kres polityce emisji pieniądza dla łatania budżetu, a podwyższyć stopę procentową dla zachęcenia ludności do oszczędzania. Rząd wietnamski konsekwentnie przestrzegał wytyczonej linii: maksymalnego wykorzystania potencjału wewnętrznego, tworzenia przejrzystych i liberalnych warunków dla przedsiębiorstw ze wszystkich sektorów, utrzymania wysokiego wzrostu gospodarczego i promowania wzrostu opartego na eksporcie. To, co osiągnęliśmy, jest zasługą rozsądnej polityki i przemyślanych przemian, które zgodne są z potrzebami i swoistymi warunkami, w jakich funkcjonuje nasze państwo.

Mimo znaczących dokonań, Wietnam jest jednak świadom ogromnych wyzwań, stojących przed nim na arenie wewnętrznej i w dziedzinie integracji międzynarodowej. Zwłaszcza zaś wyzwań, związanych z utrzymaniem wzrostu gospodarczego i zapewnieniem równego dostępu obywateli (ze wszystkich warstw społecznych i regionów) do dóbr i korzyści, jakie oferuje obecnie polityka odnowy.

${ }^{2}$ Chodzi o restrykcje dotyczące posługiwania się walutami wymienialnymi na rynku wewnętrznym. Dla legalnego płacenia nimi należało je wymienić na specjalne vouchery. Mowa zatem o liberalizacji polityki dewizowej oraz obrotu walutami wymienialnymi [Redakcja]. 
- Mimo przelomowych przemian, w Wietnamie działa wciąż znaczący sektor państwowy. Jak udało się wam pogodzić dążenie do przekształceń rynkowych $\mathrm{z}$ pozostawieniem silnego sektora państwowego? $\mathrm{W}$ innych państwach przeprowadzających procesy transformacji - własność państwowa upadła, a fabryki państwowe zbankrutowały lub zostały przejęte przez kapital rodzimy i obcy.

W ramach socjalistycznej gospodarki rynkowej, Wietnam zachęca do długoterminowego rozwoju, zdrowej i uczciwej konkurencji między wszystkimi sektorami. Sektor państwowy zaś odgrywa wciąż żywotna rolę, gdyż jest dla państwa narzędziem kierowania rozwojem makroekonomicznym i regulowania go.

W minionych latach sektory państwowy i spółdzielczy podlegały restrukturyzacji. Obecnie mamy w Wietnamie ponad 5 tys. przedsiębiorstw państwowych, 120 tys. firm prywatnych, około 4 tys. przedsiębiorstw, w które zainwestował kapitał zagraniczny oraz ponad 10 tys. spółdzielni. Ich udział w wytwarzaniu PKB jest następujący: sektor państwowy - 38,3\%, prywatny $39,8 \%$, firmy zagraniczne - 13,9\% i 7,98\% sektor spółdzielczy.

Sektor państwowy przeszedł przy tym zasadnicze zmiany. Liczba przedsiębiorstw zmalała: z dwunastu do pięciu tysięcy. Polityka odnowy zakładała, że państwo zadba o to, by przedsiębiorstwa, które przetrwały, rozszerzyły swą samodzielność finansową i mogły odgrywać istotną rolę w kluczowych dziedzinach, przyczyniając się do stabilizacji i rozwoju społeczno-gospodarczego ${ }^{3}$. Na razie przedsiębiorstwa państwowe wytwarzają wciąż 38,3\% PKB, a $40 \%$ produkcji przemysłowej, i dużo eksportują. Przysparzają więc one dochodów budżetowi pozostając wciąż głównym instrumentem realizacji polityki społecznej. Przedsiębiorstwa te przewodzą również w przejmowaniu [z zagranicy] dorobku naukowego i technologicznego. [Generalnie] mają one obecnie zdrową strukturę, a ich konkurencyjność stale rośnie.

Nadal jednak wiele z tych przedsiębiorstw przeżywa trudności, wykazuje niewydolność i niską konkurencyjność. Dlatego ważne jest, by kontynuować przekształcenia, poprawiać konkurencyjność, i umacniać ich znaczenie w gospodarce wielosektorowej. Sposobem na to mogą być przyspieszone zmiany, takie jak: dopuszczenie akcjonariatu, przekazanie zakładów w inne ręce, ich sprzedaż, lub dzierżawa. W grę wchodzą również gruntowne inwestycje, modernizacja parku technologicznego, oraz stopniowa likwidacja niektórych przedsiębiorstw państwowych.

\footnotetext{
${ }^{3}$ Reformy te przypominają stosowaną w Polsce „komercjalizację”, czyli prowadziły do przekształcenia przedsiębiorstw państwowych w samodzielne podmioty rynkowe, zarządzane przez menadżerów, jedynie z „nadzorem właścicielskim” państwa. Utrzymanie ich przy życiu było kwestią kluczową dla Wietnamu, gdyż krajowi groziło monstrualne bezrobocie w związku z koniecznością demobilizacji gigantycznej armii i ukrytym, acz bolesnym, bezrobociem na wsi, zaostrzonym przez powrót do gospodarki rodzinnej [Redakcja].
} 
- Wietnam bardzo aktywnie wspiera tendencje integracyjne w regionie. Jak w tym kontekście układają się stosunki ze Stowarzyszeniem Państw Azji Południowo - Wschodniej (ASEAN)?

Od swego przystąpienia do ASEAN [w lipcu 1995 r.], Wietnam aktywnie uczestniczy w działalności tej organizacji. W grudniu 1998 r. gościliśmy w Hanoi uczestników VI szczytu ASEAN. Był to nasz wkład do realizacji wizji ASEAN, obejmującego wszystkie 10 krajów Azji Południowo-Wschodniej. Otworzyliśmy nową kartę $\mathrm{w}$ historii rozwoju regionalnego. Ponadto Wietnam z powodzeniem przewodził 34 sesji Stałego Komitetu ASEAN, koordynował wysiłki na linii ASEAN - Rosja, ASEAN - Japonia, ASEAN - USA, a od 2003 (do 2006 r.) koordynuje prace w ramach partnerstwa: ASEAN - Australia.

W sytuacji pojawiania się wielu złożonych dylematów, potencjalnych niepokojów regionalnych i światowych, Wietnam stale współdziałał z innymi krajami ASEAN na rzecz utrzymania pokoju w regionie, stabilizacji, bezpieczeństwa i zapobiegania sporom mogącym przerodzić się w otwarte konflikty. Współdziałał z nimi, by sprostać wyłaniającym się wyzwaniom. Znakomitym osiągnięciem była Deklaracja postępowania stron w sprawie Morza Poludniowochińskiego. To wspólne dzieło głównie Wietnamu i Chin, kładące podwaliny pod dalekosiężne rozwiązanie sporów [terytorialnych] na Morzu Południowochińskim ${ }^{4}$.

Wietnam działa też w kierunku zacieśnienia współpracy w łonie ASEAN, pomagając nowym członkom w adaptowaniu się i w zmniejszaniu różnic rozwojowych. Zgłaszaliśmy rozmaite inicjatywy i podejmowali pewne kroki zmierzające w kierunku przezwyciężania problemów stojących przed Stowarzyszeniem, jak też poprawy jego funkcjonowania. Mam tu na myśli szczególnie Plan działań z Hanoi, Deklarację o likwidacji różnic rozwojowych z Hanoi, inicjatywę utworzenia Korytarza Wschód - Zachód, a także ustanowienie „gorącej linii” dla kontaktów liderów ASEAN, etc.

W sumie można skonstatować, że jako nowy członek, Wietnam wniósł znaczący wkład do działania ASEAN, przydając żywotności i dynamizmu całemu Stowarzyszeniu oraz jego stosunkom z innymi krajami.

\section{- Czy realna jest wspólna regionalna waluta na wzór euro?}

Członkowie ASEAN porozumieli się i upoważnili Malezję do pokierowania pracami studyjnymi oraz współpracą z MFW oraz z Europejskim Bankiem Centralnym. Celem będzie przygotowanie projektów dokumentów związanych z możliwościami stworzenia wspólnej waluty.

Mimo to, jej wprowadzenie potrwa zapewne długo i wymagać będzie starannych analiz, jak też uwzględnienia nierównego poziomu rozwoju poszczególnych

${ }^{4}$ Do niektórych z wysp z Archipelagu Spratly i otaczających je wód terytorialnych (prawdopodobnie z zasobami ropy i gazu, oraz bogactwem ryb), uznawanego za własne przez Chiny zgłaszają też pretensje: Wietnam, Filipiny, Malezja i Brunei. Patrz: Sharing the resources of the South China Sea, red. Mark J. Valencia i inni, University of Hawaii Press, Honolulu 1997 [Redakcja]. 
krajów [ASEAN]. Sama Unia Europejska potrzebowała wielu lat, by urzeczywistnić ideę euro.

- Rozważany jest także pomysł powołania unii celnej w ramach ASEAN...

Strefa Wolnego Handlu ASEAN (AFTA) jest niewątpliwie dobrym pomysłem. Chodzi o uruchomienie olbrzymiego rynku 500 mln konsumentów Azji Południowo-Wschodniej. Służyłoby temu wprowadzenie preferencyjnych taryf, rozszerzenie rozwiązań bezcłowych oraz zaprezentowanie obcym inwestorom atrakcyjnej oferty.

Już 1 stycznia 2002 r. podjęliśmy realizację koncepcji AFTA, najpierw z udziałem tylko sześciu członków-założycieli ASEAN. Od 2005 r. do działań tych przyłączy się Wietnam, zaś Laos i Myanmar - w 2007 r., a Kambodża - w 2009 r. AFTA ma na celu pobudzanie oraz rozwój potencjału każdego państwa członkowskiego i wzmocnienie ugrupowania ASEAN jako całości. Ma to doprowadzić do zintensyfikowania związków handlowych i możliwości inwestycyjnych, jak też do nasilenia konkurencyjności i przyspieszenia procesów integracyjnych w łonie ASEAN.

Ze swej strony Wietnam dokłada wysiłków, by postępować zgodnie z wytycznymi „mapy drogowej”, nakreślonej dla AFTA. Do 2005 r. taryfy wewnątrz ASEAN ulegną obniżeniu do poziomu pół procenta. Jednocześnie reformy zmierzać będą do tego, by upowszechnić reguły otwartego handlu, odpowiadające praktykom międzynarodowym.

- Wietnam zabiega o dobre stosunki z Chinami. I to się udaje. Utrzymuje też kontakty z Tajwanem. Tajwańska dyplomacja i biznesmeni starają się rozwijać aktywność w Wietnamie. Jak reaguje na to Hanoi?

Chiny i Wietnam sąsiadują ze sobą. Wiąże je tradycyjna przyjaźń. Łączy nas wiele wspólnego w kulturze, obyczajach i tradycjach, występują też pewne podobieństwa społeczno-polityczne. To istotne czynniki dla rozwoju stosunków między naszymi krajami. Tak było w przedtem, tak jest dziś, i tak będzie w przyszłości. Od początku normalizacji [wzajemnych relacji w 1991 r.], stosunki nasze uległy scementowaniu i pogłębieniu.

Co roku obydwie strony odbywają regularne spotkania na najwyższym szczeblu, dokonuje się wymiany wizyt [rządowych], a także rozwijają się kontakty na poziomie różnych agencji i społeczności lokalnych. Pomaga to skonsolidować naszą przyjaźń i współpracę. Podczas wizyt na najwyższym szczeblu przywódcy zawsze akcentują wolę umocnienia stosunków dwustronnych, zgodnie z hasłem: „dobre sąsiedztwo, rozległe współdziałanie, długofalowa stabilizacja i spojrzenie w przyszłość".

Dotychczas obydwie strony podpisały 45 umów państwowych, stanowiących podstawę prawną dla naszej długoterminowej współpracy. Podpisano, m.in. Traktat o granicy lądowej, Traktat o delimitacji Cieśniny Tonkińskiej i Traktat o wspótpracy wrybolówstwie, co stało się fundamentem tworzenia na granicy wietnamsko-chiń- 
skiej stosunków pokoju i przyjaźni. Uruchomiliśmy znowu połączenia drogowe, lotnicze, morskie i kolejowe, by ułatwić przepływ towarów i ruch pasażerów.

Stosunki polityczne, gospodarcze, w tym handlowe, rozwijają się w sposób napawający optymizmem. Wymiana handlowa między naszymi krajami wzrosła niebywale. W 2002 r. jej wartość wyniosła 3300 mln USD, podczas gdy w 1992 r. sięgała jedynie sumy $266 \mathrm{mln}$ USD. Tylko w pierwszych 8 miesiącach 2003 roku wzajemna wymiana handlowa przekroczyła 3 mld USD. W 2005 roku przewidujemy osiągnięcie pułapu 5 mld USD. Jeśli chodzi o inwestycje, to rząd chiński udostępnił Wietnamowi bezzwrotną pomoc i kredyty preferencyjne. Zostały one przeznaczone na urzeczywistnienie takich projektów jak: unowocześnienie stalowni Thai Guyen i fabryki nawozów Bac Giang, a także na wydobycie miedzi w Sin Quyen.

Rząd wietnamski przywiązuje dużą wagę do rozwoju i umocnienia przyjaźni oraz stabilności w stosunkach z Chinami. Uważamy, że dobre i trwałe stosunki między Wietnamem i Chinami służyć będą fundamentalnym interesom obydwu narodów, przyczyniać się do pokoju, stabilizacji, współpracy i rozwoju regionu oraz świata.

Co się tyczy Wietnamu i Tajwanu, to utrzymują one jedynie stosunki kulturalne, a także gospodarcze i handlowe, choć mają one niejako charakter pozarządowy. Punktem wyjścia jest polityka ,jednych Chin" [przyjmowana przez nasz kraj].

- Jak Pan Prezydent określiłby miejsce oraz rangę wietnamskich tradycji, jak też tradycyjnych wartości narodowych w Wietnamie, który szybko modernizuje się teraz i posuwa naprzód?

Postawiliśmy przede wszystkim na kulturę, jako fundament społeczeństwa. Pielęgnowanie i propagowanie kultury jest nie tylko celem, ale i bodźcem dla stałego rozwoju społecznego i gospodarczego. Oto podstawowa linia polityczna władz Wietnamu: wspomaganie rozwoju oświaty i szkolnictwa, a także nauki i techniki. Zarazem stale poświęcamy wiele uwagi zachowaniu i upowszechnianiu kultury wietnamskiej, przepojonej poczuciem narodowej tożsamości. Tylko taka kultura dziedziczyć może i prowadzić do rozkwitu takich tradycyjnych wartości, jak: patriotyzm, duch wspólnotowy, jedność, pomoc wzajemna, przedsiębiorczość, etc. Jednak kwintesencję kultury ludzkiej stanowi współpraca i wzajemne spotykanie się [rozmaitych] tradycji narodowych oraz ich wzajemne przenikanie.

W przeszłości, wraz z osiągnięciami w sferze społeczno-gospodarczej, Wietnam odnosił wielkie sukcesy także na polu kultury. Współczesne poczucie wartości moralnych i [standardy] moralnego stylu życia, zgodne z narodowymi tradycjami i obyczajami, zakorzeniły się i rozwinęły we wszystkich warstwach społecznych. Przywrócono i promuje się znowu tradycyjne święta, uroczystości kulturalne i gatunki sztuki takie jak, np.: dramat klasyczny, opera ludowa, zreformowany [tj. uwspółcześniony] teatr, duety miłosne, teatr lalkowy na wodzie itp. Sztuka współczesna 
też przeżywa twórczy rozkwit. Wspieramy sztukę i kulturę mniejszości etnicznych, a wymiana kulturalna z zagranicą znacznie zwiększyła się.

Jednakże, mimo wspomnianych dokonań, istnieją naturalnie pewne niedociągnięcia, które należy szybko usunąć. Dlatego też państwo powinno zwracać baczniejszą uwagę na ochronę rodzimego dziedzictwa kulturowego i na kształtowanie nowych wartości kultury po to, by sprostać dzisiejszym potrzebom ludzi. Pilną sprawą stało się zapobieganie ślepemu przejmowaniu obcych wzorów, sprzecznych $\mathrm{z}$ wartościom kultury narodowej, $\mathrm{z}$ drugiej zaś strony przeciwdziałanie występującej ostatnio orientacji całych grup społecznych na kierowanie się jedynie kryteriami czysto utylitarnymi oraz prowadzenie [nazbyt] egoistycznego trybu życia.

- Karierę zrobilo w świecie pojęcie wartości azjatyckich. Ideologię te mocno uwypuklał i lansował premier Malezji, Mahathir Mohammad. Był jej głównym chorążym. Jak Pan Prezydent odnosi się do tej idei i jak zdefiniowałby Pan wartości azjatyckie?

Odkąd rodzaj ludzki pojawił się na ziemi, pojawiały się też w dziejach rozmaite formy bytu i rozwoju społecznego. Występowała, na przykład, różnorodność ras, pochodzenia, tradycji i obyczajów, języków, wierzeń religijnych, tożsamości zbiorowych i kultur. Różnorodność wspólnoty ludzkiej wskazuje na żywotność różnych tradycyjnych wartości, w sferze kultury, myśli i poglądów. Współistnieją one ze sobą, uzupełniają się i razem rozkwitają. Jest to bezcenna spuścizna, wynikająca ze wspólnej ewolucji rodzaju ludzkiego.

Co zaś tyczy się wartości azjatyckich i wspaniałych azjatyckich osiągnięć [w rozwoju gospodarczym], wielu badaczy z różnych krajów wskazywało na pewne czynniki tradycji, jak na przykład ze sfery myśli, tradycji ducha wspólnotowego i [modelu] edukacji. Występowało przy tym twórcze przyswajanie sobie cywilizacji ogólnoludzkiej i kultywowanie zarazem własnej - narodów azjatyckich. Z tej perspektywy, jak myślę, należy ujmować wartości azjatyckie.

Jako członek wspólnoty azjatyckiej, Wietnam zawsze szanował tradycje kulturalne i wartości duchowe każdego kraju, a także jego tożsamość. Uznawanie wspólnych wartości, a jednocześnie poszanowanie [każdej] kultury - to najlepsze podejście do sprawy. Szczególnie dlatego, że żyjemy w czasach dywersyfikacji, zróżnicowania kultur, tworzącego strukturę współczesnej cywilizacji.

Poglądy [byłego] premiera Malezji Mahathira Mohammada na wartości azjatyckie zostały jasno wyłożone w jego książce Nowy lad dla Azji (New Deal for Asia). Wietnam wysoko ceni jego rolę w wypracowaniu i realizacji polityki przyspieszonego rozwoju współczesnej Malezji, jak również jego koncepcje wartości azjatyckich.

- Wietnam łączą coraz lepsze stosunki z USA. Jak duże znaczenie mają one dla Wietnamu? Czy są już jednym z motorów napędowych wzrostu gospodarczego Pana kraju? 
Wietnam i Stany Zjednoczone nawiązały oficjalne stosunki dyplomatyczne w 1995 r. Odtąd, szczególnie od czasu podpisania Dwustronnej umowy handlowej, która weszła w życie 10 grudnia 2001 roku, stosunki między obydwoma krajami cechował pozytywny rozwój. Następowała częsta wymiana wizyt na szczeblu rządowym, parlamentarnym, ministerialnym, branżowym i organizacji masowych, co sprzyjało lepszemu zrozumieniu. Miało to istotny wkład do systematycznego promowania i poszerzania współpracy w różnych sferach: na polu polityki, gospodarki, kultury, nauki i techniki, ochrony zdrowia i środowiska naturalnego, szkolnictwa i kształcenia, a ostatnio także zwalczania terroryzmu.

Jeśli chodzi o współpracę gospodarczą, handlową i kooperację inwestycyjną, to obydwa kraje zawarły wiele porozumien dotyczących handlu, ochrony własności intelektualnej, działalności Korporacji Prywatnych Inwestycji Zagranicznych (OPIC). To tworzy niezbędną bazę prawną. USA nie powracają już do stosowania poprawki Jacksona-Vanika wobec Wietnamu ${ }^{5}$, i udzielają nam pomocy technicznej w realizacji umów handlowych, popierają również nasze wejście do Światowej Organizacji Handlu (WTO). Chcą również współpracować z Wietnamem przy rozstrzyganiu sporów handlowych.

Od podpisania umowy handlowej, czyli od grudnia 2001 roku, handel dwustronny zwiększył się kolosalnie. W gronie 232 partnerów handlowych USA Wietnam plasuje się dziś na miejscu 33 (a był na 56). W 2002 r., obroty dwustronne wyniosły prawie 2 mld $900 \mathrm{mln}$ dolarów, co stanowiło wzrost o $95 \% \mathrm{w}$ porównaniu do roku poprzedniego. W początkowych siedmiu miesiącach 2003 r., obroty wzajemne przekroczyły 3 mld USD. Za cały 2003 rok osiągną one zapewne okrągłą sumę 4 mld USD. Chociaż inwestycje amerykańskie w Wietnamie wzrastają, to nadal pozostają na skromnym poziomie. Dotychczas Stany Zjednoczone wdrożyły 171 projektów inwestycyjnych o łącznej wartości $1600 \mathrm{mln}$ USD. To daje Ameryce dopiero 11 miejsce na liście największych inwestorów w naszym kraju.

Nie możemy też narzekać na stosunki między Wietnamem a USA w sferze wymiany kulturalnej, oświaty i kształcenia, a także na współpracę w sprawach humanitarnych, jak poszukiwania zaginionych podczas wojny żołnierzy amerykańskich, rozminowywanie [dawnych terenów wojennych], badania nad wpływem broni biologicznej [na ludzi i środowisko, tj. długoterminowych skutków jej stosowania przez USA podczas wojny]. Pomaga to lepszemu zrozumieniu i współdziałaniu między obydwoma rządami i narodami.

Mimo to nadal dzielą nas jednak pewne różnice zdań i konflikty interesów w takich sprawach, jak prawa człowieka, stosunek do religii, a ostatnio również - spra-

\footnotetext{
${ }^{5}$ Została ona przyjęta w 1975 r. przez Kongres, a zabraniała przyznawania tzw. klauzuli najwyższego uprzywilejowania w handlu z USA tym państwom, które nie zezwalają na swobodną emigrację swym obywatelom. Wymierzona ona była przeciwko Związkowi Radzieckiemu i wiązała się z utrudnieniami emigracji tamtejszych Żydów do Izraela. Rozciągnięto ją również na Wietnam w związku z problemem nielegalnej emigracji tzw. „boat people” [Redakcja].
} 
wy handlu. Można się jednak porozumieć, jeśli uwzględni się specyficzne warunki każdego kraju. Wyznaję pogląd, że rozbieżności powinny być wyjaśniane na drodze dialogu, w duchu wzajemnego zrozumienia i poszanowania, nieingerencji w sprawy wewnętrzne, równości i wzajemnych korzyści.

Wietnam pragnie budować stabilne i trwałe stosunki z USA, stosownie do potencjału obydwu stron. To leży z całą pewnością w interesie obydwu narodów, i stanowiłoby wkład do dzieła utrwalania pokoju, rozwoju współpracy oraz pomyślności każdego z naszych państw, jak też regionu [Pacyfiku] i całego świata.

\section{- Bardzo dziękuję Panu Prezydentowi.}

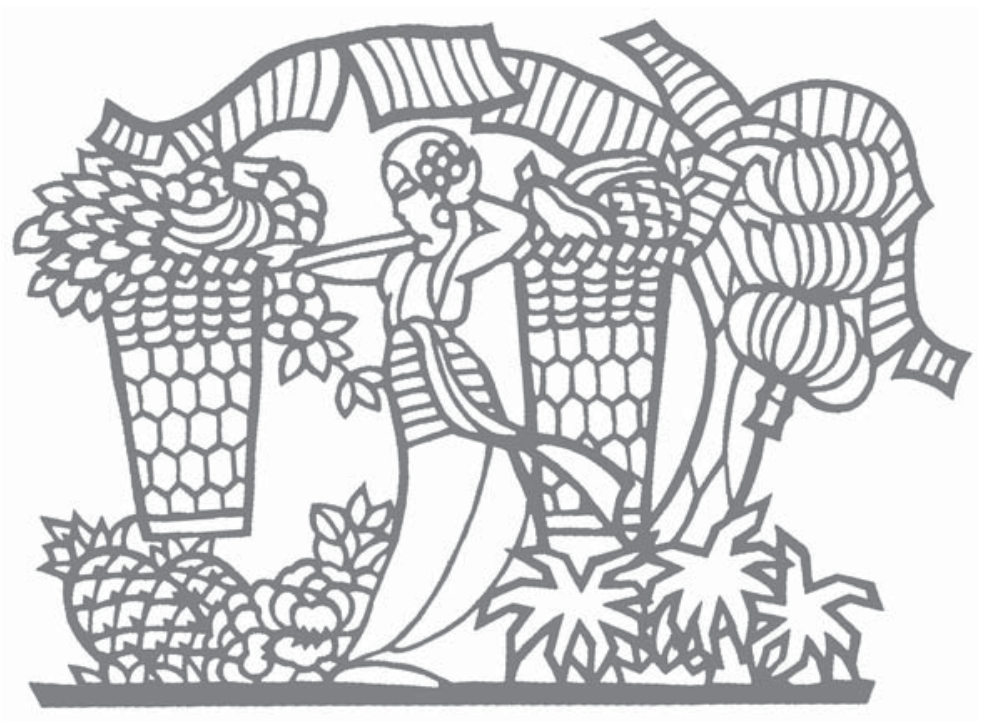

